\title{
2. METHODS, CONVENTIONS, AND GENERAL OBSERVATIONS
}

\author{
E. L. Gealy, E. L. Winterer, Scripps Institution of Oceanography, La Jolla, California \\ and \\ R. Moberly, Jr., Hawaii Institute of Geophysics
}

\section{SYSTEM OF NUMBERING HOLES AND CORES, AND LOCATING SAMPLES}

Each drilling site has a number, for example, 61, and each hole drilled at the same site is identified by a decimal number: the first hole at Site 61 is Hole 61.0, the second hole is 61.1.

The cores recovered from each hole are numbered successively in the order in which they were taken: Core 1, Core 2, etc. The core barrels used on Leg 7 were of two lengths: 30 and 31 feet (9.1 and 9.4 meters). Because of the many uncertainties in determining depths in the drill holes, the depth from which cores were taken is given in this report only to the nearest meter.

When the core barrel is recovered on the deck of the drilling vessel, the core catcher is removed from the core barrel, and any material in the catcher (as much as 25 centimeters in length in some cores) is labeled "core catcher", or CC. The plastic core liner is withdrawn from the core barrel and cut into 150-centimeter lengths called sections, beginning at the lower end of the barrel. A 9.4-meter liner can be cut into six such sections, with a short section-about 40 centimeters in length-at the top end. The sections are numbered according to the amount of material recovered: In a full barrel, the short uppermost section is called the "zero" section, and the first 150-centimeter section below that is Section 1, the next Section 2, etc. When the barrel is only partly filled with core material, the cutting of the liner into 150-centimeter sections proceeds as usual, starting from the bottom of the liner. The labeling, however, begins with the uppermost 150-centimeter section in which there is core material: that section, even if only partly full, is Section 1, the next below is Section 2, etc. The following diagrams will make this convention clear.



Partly

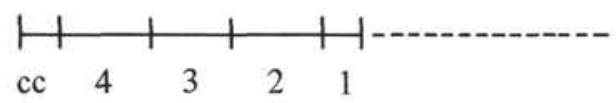

Within each section, individual samples or observations are located by measuring in centimeters down from the top of the section. This is true even when a section is not full of material, either because of original want of recovered material (a short Section 1, for example), or because of voids produced by compaction or shrinkage.

In using the Visual Core Description as a guide to ordering samples, the reader is cautioned that the core material, especially if it is unconsolidated or watery, has a tendency to shift up or down within the core liner, and that a feature located at, say, 43 centimeters on the Description may be shifted to 46 centimeters on account of compaction caused by handling of the core. This effect is observable in many Visual Core Description sheets where there is a discrepancy in position between features drawn in the graphic column as compared to the same features on the core photographs.

\section{REPRESENTATIVENESS OF CORES}

Because most of the results reported in this volume are based on cores retrieved on Leg 7, and because future scientific work will be based on samples taken from these cores and on data related to them, the question of how representative, these cores are of rocks in in situ becomes important. Not only does the representativeness of the cores vary widely from sample to sample, but the reliability of the information that can be extracted from the cores depends on the type of information being sought. This section describes the drilling, coring, recovery and sampling processes in terms of their effects on the cores, and how these effects may be related to some of the properties being studied.

\section{Summary of Coring and Core Handling Procedures}

The materials retrieved by coring can best be evaluated if the conditions under which they were taken and processed are understood.

Cores are retrieved aboard the Glomar Challenger by the punch core-rotary drilling method, wherein a drilling assembly approximately 10.75 inches in diameter, which has a bit opening of 2.5 inches in diameter, is lowered on a drill string to the ocean floor. In semiconsolidated sediments, the drilling assembly is 
rotated, and drilling fluid (most commonly seawater) is forced down the drill pipe around the outside of the coring assembly, and out of openings above the bit. The sediment material cut away by the bit becomes mixed with the drilling fluid and is lifted to the sea floor along the annulus between the drill string and outside of the hole. The cores are retrieved in a free floating core barrel. The bottom of the core barrel rests on a lower support bearing; the upper end is held down by a latch, and there is a swivel bearing between the barrel itself and the latch. Thus, the core barrel can remain fixed in space as the drilling assembly rotates around it. Commonly, the core barrel rotates with the drilling assembly until friction between the cored material entering the barrel is sufficient to hold the barrel stationary.

It can be seen at once that a perfect balance must be maintained among the rate of descent of the drill string, the fluid pressure, and the speed of rotation to avoid the extremes of washing out a hole by fluid jetting ahead of the bit (where no core is retrieved) and using so little water and rotating at so slow a speed that core cutting is inhibited, the risk of sticking in the hole is increased, or the sediments retrieved are excessively compacted.

The desirable balance differs with the nature of the rocks being penetrated. In soft sediments-if no core is required, it is common to "wash down", using only the jet action of the water plus the weight of the drill string. If a core is desired in soft sediments, it is common to allow the drilling assembly to sink into the sediments under its own weight with little or no fluid pressure, and little or no rotation at the drilling assembly. In some cases, this technique permits the recovery of good, relatively undisturbed cores; in other cases, most of the volume of the sediments displaced by the drilling assembly (more than ten times the capacity of the core barrel) is extruded into the core barrel. At Hole 62.1, in drilling Core 34, twenty-one feet ( 6.4 meters) were penetrated and thirty feet $(9.1$ meters) were recovered. In Hole 64.1, in drilling Core 7 , seven feet (2.1 meters) were penetrated and seventeen feet (5.2 meters) were recovered. At Site 66, in drilling Core 8 , twenty-four feet ( 7.3 meters) were penetrated and thirty feet ( 9.1 meters) were recovered. Distortion produced by this phenomenon is usually quite obvious. Color variations in the sediment due to mottling or bedding may be highly contorted. The sediment layers have a diapiric appearance and some are vertically oriented. Good examples are: 7-62.1-6-3 through -6 (in nannofossil chalk ooze), 7-66.1-2-1 through -6 (in radiolarian ooze), and 7-63.0-1-1 through -4 (in pelagic brown clay). The amount of distortion varies from complete extrusion to intact cores with horizontal bedding planes.
In more indurated rocks, it is necessary to use higher fluid pressures and to rotate the drilling assembly more rapidly in order to cut the cores. The driller commonly releases the brake, increasing the weight of the drilling assembly on the bit face, then rests while circulating and rotating until a drop in fluid pressure indicates that some drilling progress has been made. The brake is released again, and another segment is cut, etc. In some places on Leg 7, where the brake was released, a segment of rock several centimeters or tens of centimeters in length would be cut. This segment would then be broken off, and the next segment of rock would be ground into a paste and the paste forced into the core barrel. This alternation of intact core and drilling paste is especially common in the chalks at Sites 62, 63 and 64 (for example, 7-64.0, Cores 4 through 7), but was also found in stiff pelagic clay (7-66.0-8, Cores 3 and 4) and radiolarian ooze (7-66.1-6, Cores 2 through 6). Some of the soft layers in the chalk-ooze sequences appear not to be pulverized, but are simply unconsolidated and intact, as shown by evidence of bedding and, in some places, a gradient in induration. Distinguishing between the naturally soft chalk and the artifact is difficult in some cases. An example of thin, alternating indurated and unconsolidated beds in a chalk-ooze sequence shattered by the drilling process but not injected with drilling paste is $7-64.0-10$, Sections 1 and -2 .

After recovery, cores are cut into sections of 1.5meters length. These sections are weighed, the natural gamma radiation measured, the gamma-ray attenuation measured (for saturated bulk density), the sections X-rayed and sonic velocity measurements made. Details of these procedures are described elsewhere in this volume.

Most core sections are then split longitudinally. Sections containing material in a very liquid state generally are not opened. For cores of plastic sediments, the core liner is cut on either side with an electric saw, and the core materials sliced with a wire. Most such cores are little damaged by the cutting process, except that the surface is smeared. Where pyrite nodules, loose cavings of chert or rust flakes, or the plastic sock used as a core catcher are present, the plastic sediments are disturbed by the slicing process-sometimes severely. Semiindurated sediments are cut with a saw blade. This technique tends to be quite damaging, particularly in sequences of alternating layers of indurated chalk and soft calcareous ooze, where the splitting process completes the fragmenting begun by the coring process. When sections of indurated rock are split, an electric saw is used to cut toward the middle from opposite sides. This procedure usually leaves a ridge of shelf in the middle of the section half, and this is visible on the photographs. 


\section{Relationship Between Rocks in Place and Recovered Materials}

It is obvious that some cores retrieved are representative of the rocks in situ with respect to some properties. In other cases, it is obvious that they are not. Most cores retrieved are between those two extremes.

Three fundamental problems result from the coring and handling techniques described above. First, the materials retrieved undergo a shift in properties simply by being removed from their in situ environment to the laboratory environment. Second, the process of recovering the core improperly samples the rock in place, and tends to mix, displace, disturb or contaminate the retrieved materials. Third, the process of splitting the core sections and sampling them in the laboratory introduces more disturbances. These effects are discussed below.

\section{Depth Below the Sea Floor of Core Barrels and Their Stratigraphic Sequence}

The depth of the cored interval below the sea floor cannot be known with precision. The distance between the sea floor and the top of the cored interval was estimated in the following manner. The distance between the drill floor and sea bottom was determined from the precision depth recorder. This figure was subtracted from the length of the drill string at the time that the coring operation began, as estimated by the driller. The driller lifted the drill string to allow the bumper subs to stretch to their open position; he then lowered the drill string to the bottom of the hole, and estimated the length of the drill string at the point where the weight on the draw works brake first decreased. These estimates are probably accurate to within a few meters, but great precision cannot be expected. On some occasions, unknown to the driller, the bumper subs were jammed in a partially closed position, thus rendering his estimate of drill string length inaccurate.

The distance between the drilling platform and the sea bottom varies because the ship heaves (the heave is usually less than one meter and rarely more than three meters); because the elasticity of the drill string and the presence of bumper subs renders the absolute length of the drill string uncertain; and, because the drill string, particularly in the sediments themselves, is known to deviate from the vertical-sometimes substantially. Depths reported for particular core barrels are believed to be accurate to within a few meters, but they certainly are not accurate to the exact centimeter. Standard practice is to core about 30 feet ( 9.1 meters), and recovery is commonly 30 feet ( 9.1 meters). As pointed out above, in soft sediment, the entire 30 feet (9.1 meters) may be recovered from the first few feet penetrated. When recovery was less than 30 feet $(9.1$ meters), our practice on Leg 7 was to assign the recovered core to the upper part of the cored interval. This practice is based on the assumption that either a fragment jammed in the core barrel or friction prevented entry of lower materials, or that the power part of the core was lost through the core catcher. In some cases, however, circulating drilling fluid may have washed away the upper part of the interval intended to be cored, and the recovered part might actually have been from the lower portion of the stratigraphic interval penetrated.

In places where continuous coring is attempted, the question arises as to whether the cores are in true stratigraphic sequence. During the period between the time that retrieval of one core barrel begins and the onset of the next coring operation, the motion of the ship causes the drill string to move, and the absolute distance between the sea floor and the drill bit changes, usually only a small amount. Further, because cavings accumulate at the bottom of the hole during this period, it is common to lift the drill bit slightly off the ocean floor to avoid sticking. Consequently, consecutive core barrels may overlap somewhat stratigraphically or, more rarely, have a stratigraphic gap between them. Stratigraphic overlap may occur because neither the holes nor the drill string are always plumb, and a core barrel can cut into fresh sediment above the maximum depth reached by the previous core barrel.

When more than one hole is drilled, the problem of stratigraphic sequence becomes more acute, a mismatches of horizons at the same depth in different holes are common. A particularly troublesome example of this occurred at a depth of 140 meters at Site 63, where the cores recovered in 63.0-3 appear to be stratigraphically lower than those recovered at 63.1-9.

\section{Completeness and Stratigraphic Reliability of Materials Recovered in a Core}

The ratio between the amount of material recovered and the footage penetrated is highly variable. There may be no recovery; a few fragments may be caught in the core catcher; or, part or all of the section may be recovered. The very soft oozes near the sea floor were seldom recovered. The first materials recovered were commonly mixed slurries of sediment and seawater representing materials within a few meters or tens of meters of the sea floor.

A full core barrel is no guarantee of representativeness. As described above, in the soft upper layers, in particular, sediments may fill the core barrel to a height greater than the interval penetrated. Also, the fact that the number of feet recovered is equal to or less than the number of feet penetrated is no guarantee that the recovered material is complete or in proper sequence. The drilling techniques used are such that in 
alternating sequences of hard and soft beds, the hard beds tend to be recovered, whereas the intervening soft ones sometimes are not. Further, it is not uncommon for a paste consisting of pulverized rock (described above), or even a naturally plastic sediment from another stratigraphic interval to be intruded in partings between more indurated layers, although, more commonly, these pastes are injected along the walls of the core liner. This artificial bedding is often difficult to distinguish from natural bedding.

\section{Disturbance of Materials Within a Core Barrel}

Materials may be fragmented or homogenized by the coring process. The chert layers, thin beds of silicified siltstone, and limestone interbedded with softer materials are often fragmented forming a breccia and paste mixture. Dolomite in Core 7 at Hole 62.0 was recovered both as large fragments and as a "sand" of dolomite rhombs.

Materials may become sorted or compacted by the coring process. In the semiconsolidated sediments, some sorting takes place by vibration during the coring and recovery process, the more dense components settling into the lower part of the core barrel. There is also a tendency for the sediments to compact as the cores are forced into the core barrel. Friction between the core and the liner increases as the core enters the barrel, and the last few centimeters of core to enter the core barrel are most compacted. Both of these disturbances tend to make the lowest section in a core bed more dense than the uppermost section. To determine how pervasive these effects are, values of saturated bulk density derived from the weight of the whole section (where the sections were full) were averaged by section number for all cores at Site 62 .

$$
\begin{aligned}
& \text { Section 1, average } \rho \mathrm{B}=1.82 . \\
& \text { Section 2, average } \rho \mathrm{B}=1.82 . \\
& \text { Section 3, average } \rho \mathrm{B}=1.83 . \\
& \text { Section 4, average } \rho \mathrm{B}=1.84 . \\
& \text { Section 5, average } \rho \mathrm{B}=1.84 . \\
& \text { Section 6, average } \rho \mathrm{B}=1.85 .
\end{aligned}
$$

This increase in saturated bulk density of 0.03 from the top to the bottom of a core is almost certainly an artifact. The average increase in saturated levels of density with depth is only 0.078 per 100 meters from the top to the bottom of a core barrel, or about 0.006 . The actual amount of sorting or compaction present is, of course, highly variable. The sorting is greatest in the unconsolidated materials near the surface; the compaction effects are greatest in the semiconsolidated materials beneath them.

Materials may be reoriented within the core barrel. There is evidence to indicate that sometimes the core barrel rotates with the drilling assembly and some cohesive plastic sediments twist up the core barrel in corkscrew fashion. Occasionally, an animal burrow boring is seen to be so twisted. Thus, even though bedding may appear to be intact in incorrect stratigraphic sequence, the horizontal orientation has been disturbed. Occasionally, discrete pieces of sediment are rotated about a non-vertical axis. Such rotation is usually obvious, but may be obscured in homogeneous sediments.

\section{Contamination}

Materials may become contaminated with drilling fluid (seawater on this cruise), with previously drilled material, or with scale and grease from the drill string. Instances of contamination were common in some holes, but rare in others. Beds of chert, porcelanite limestone, indurated volcanic sandstone, or wellindurated mudstone might be fractured when penetrated and not all the fragments could be circulated out. Before the next core, fragments would sink to the bottom of the hole, and subsequently be cored. The most striking instance was at Site 67, in both cores.

Abundant rust flakes contaminated several cores of Site 66, the deepest site of Leg 7. The pipe racks were emptied, and several of the last stands of pipe used were used for the first time in several months. They had rusted badly on the inside, and the rust was carried into the core by the circulation.

After each site, the drilling crews were careful about collapsing the bumper subs, extruding rock fragments that lodged in the splines. Nevertheless, in a few instances, at the next site there would appear some fragments of distinctive lithology, indicating contamination of the cores from material carried from the previous site.

\section{Disturbances of Materials by Removal from In Situ to Laboratory Environment}

Considering the profound effect of the drilling and coring disturbances on the gross properties of the cores, it may seem justifiable to ignore the effects of removing the cored materials from in situ pressure and temperature conditions to laboratory conditions. The effects of thermal expansion can be ignored. The thermal expansion of any marine sediment encountered due to a change in temperature from $4^{\circ} \mathrm{C}$. to $20^{\circ} \mathrm{C}$. should be less than 1.001 (volume) and is probably of the order of 1.0002 to 1.0006 (volume) (after Skinner, 1966). However, the effects of the change in environment on the geochemistry of the sediments and their interstitial water (discussed below) are considerable, and the effect of the release in 
confining pressure on the volume and porosity of the sediments recovered may be substantial.

Some assistance in evaluating the effects of removing samples from in situ to laboratory conditions may be provided by information from Site 29 in the Caribbean (Leg 4), where a section of Lower Miocene marls and calcareous clays and Upper to Middle Eocene radiolarian oozes and cherty radiolarites were penetrated from 117 to 230 meters below the sea floor (Gealy and Gerard, 1970). In situ measurements of electrical properties, natural radioactivity, and porosity (by neutron logging) were made. Also, the sequences were cored extensively, permitting measurements made on the cores to be compared with their in situ equivalents. Results of some of these comparisons are described in some of the paragraphs below, and may permit further evaluation of measurements made on cores recovered on this leg.

The amount of elastic rebound due to the release of cores from in situ overburden pressure is difficult to assess. At Site 29, on $\operatorname{Leg} 4$, when values of porosity measured on cores were compared with values derived from in situ neutron logging, it was found that the porosity of the cores was consistently higher than the in situ equivalents, and that the differences increased with depth below the sea floor. Cores of Middle Eocene radiolarian ooze at 170 meters beneath the sea floor had a porosity of 81 per cent, whereas equivalent in situ values of porosity were only 62 per cent. Because the cores showed no evidence of having been extensively mixed (mottling and bedding were little disturbed) and because the radiolarian ooze showed considerable elastic rebound when depressed with the fingertips, it was concluded that the difference between the porosities measured on the cores and in situ values were due almost entirely to elastic rebound.

\section{Effects of Coring and Processing on Parameters Studied}

\section{Effects on Biostratigraphic Studies}

The effects of these disturbances on biostratigraphic information which may be derived from the cores is variable. Laboratory processing does not seriously disturb the cores for micropaleontological work, except for smearing of the core surface with the slicing tool, which makes it advisable to scrape the core surface before taking small nannofossil (or smear slide) samples. Disturbances due to coring and recovery are more serious. The outer surface of the core (near the core liner) is almost always contaminated and is unreliable for any kind of investigation. In the following diagrams, consecutively-lettered units are assumed to have had similar in situ thicknesses, and each rectangular box (heavy outline) represents a core. The coring process can:

a. Exclude sediments from some levels within a core.

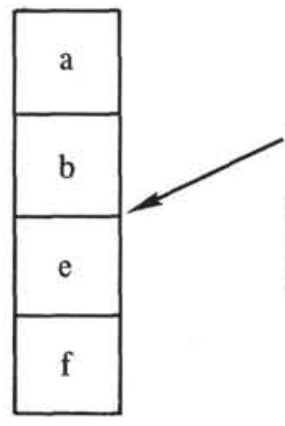

and $\mathrm{d}$ excluded

(Too much circulation. Different types of sediment selectively retained.

b. Oversample some sequences.

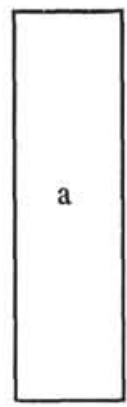

c. Cause hiatuses between cores in an apparently continuously cored sequence.

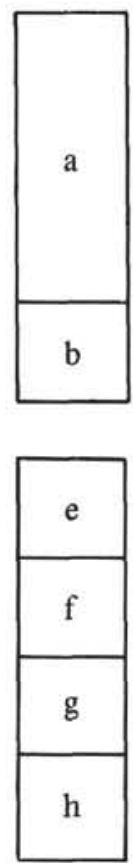

(The barrels being filled partly with out-of-place materials or oversampling of some intervals.) 
d. Sample cavings (at the top of the core barrel) at the bottom of the

hole.

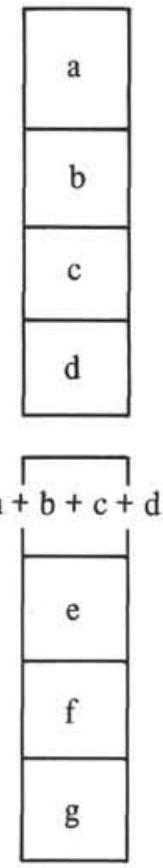

e. Sample cavings (at the bottom of the core barrel) at the bottom of the hole by bouncing the bit on the bottom of the hole.

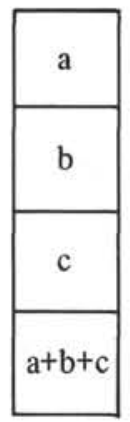

Good example in the radiolarian and silicoflagellate reports on 66.0-1 and 66.1-3, Sections 4 and 5.

f. Introduce mixtures between the in situ materials.

\begin{tabular}{|c|}
\hline$c$ \\
\hline$a+b+c$ \\
\hline$d$ \\
\hline$b+c+d$ \\
\hline$e$ \\
\hline$c+d+e$ \\
\hline$f$ \\
\hline$d+e+f$ \\
\hline
\end{tabular}

(Alternately coring in situ materials and cavings.)
These disturbances affect all measurements, including paleontological ones, but some of the phenomena can be best detected paleontologically.

\section{Effects on Physical Properties}

Physical properties are best measured in situ by means of petro-physical devices suspended in the hole, as the measurements are made on relatively undisturbed material in place. Unfortunately, no logging capability was provided for Leg 7. Therefore, laboratory measurements of physical properties on the cores have been provided wherever possible, even though such data must be utilized with judicious understanding of the conditions under which they were obtained.

In many cases, the problem of core disturbance was so serious as to render measurements of physical properties meaningless with respect to in situ conditions. Where disturbances in the opinion of the shipboard party were this severe, either measurements were not made, or appropriate notations accompany the data presented.

The drilling and coring process can cause the porosity (and saturated bulk density) of the cores to be either higher or lower than their in situ equivalents. Dilution with drilling fluid, of course, increases the porosity of the cores. Artificial compaction reduces it. The sorting described above does both. At Site 29 in Leg 4, it was found that almost all cores were more porous than their in situ equivalents, and the difference in porosity increased with the depth of burial, the radiolarian ooze showing an increase in porosity of 20 per cent at a depth of 170 meters below the sea floor. This indicates that all porosity values measured on cores should be viewed with caution; most are probably higher than their in situ equivalents. Measurements of porosity of the radiolarian oozes cored at Sites 65 and 66 are particularly suspect. The porosities of radiolarian ooze near the sea floor may be reasonably reliable, but the error probably increases with depth, and the porosity of 80 per cent at 160 meters below the sea floor noted at Site 65 may in fact be as low as 60 per cent.

As described above, soft lithified chalks were frequently recovered as alternating segments of intact cores and pulverized drilling paste. In order to determine whether this pulverizing action had any effect on the porosity of the material, six pairs of samples of biscuit and paste were selected as close to each other in the cored section as possible, and their porosities were measured. These measurements are discussed elsewhere in this volume. The porosities of the samples of intact chalk range from 40.7 to 62.7 per cent. Of the six pulverized samples, four showed a decrease in porosity from their intact equivalents of from 0.6 to 7.0 per cent. Two samples showed an increase of about 2.0 per cent. 
The effects of these disturbances on the elastic properties of the cores is profound. Measurements of the sonic velocity made through the liner may differ substantially from those that would result from measurements made in situ, and these measurements are discussed in more detail in the chapter on Sound Velocity.

\section{Effects on Petrographic Studies}

Coring disturbances affect the petrology of the cores primarily by displacing materials so that they are not recovered at their proper stratigraphic level, by mixing, by contamination, and by selective recovery. In addition, they have a serious effect on the fabric and sedimentary structure of the softer sediments, although many of the cores of softer materials retain enough of their former shape to permit detection of structure and fabric. However, some distortion is almost invariable. The identification of penecontemporaneous deformation in soft sediment is suspect. Sedimentary structures are well preserved in the lithified sequences, and are particularly conspicuous in the chalks. Except where samples are from displaced or contaminated materials, mineralogy and measurements of size analysis should not be affected adversely by the handling process.

\section{Effects on Measurements of Natural Gamma Radiation}

Assuming that the radiation is due primarily to the solid components of the sediments, cores consolidated by the recovery process will show higher natural gamma radiation than their in situ equivalents. Conversely, materials diluted with drilling fluid will show a lower radioactivity. At Site 29 of Leg 4, it was found that-when measurements of the natural gamma radiation of cores were compared with gamma ray measurements made in situ-in the alternating layers or more dense, less radioactive calcareous marls and in the less dense, more radioactive noncalcareous clays, the clays were selectively washed out, and the recovered materials showed a higher density and lower radioactivity than their in situ equivalents. This selective recovery should have little effect on the natural gamma radiation measured in sequences showing very uniform radioactivity, as at Sites 62 and 64 and the lower part of Site 63 . However, the effects may be considerable in sequences of alternating lithologies, as in the lower part of Site 65.

\section{Effects of Coring and Processing on Geochemistry ${ }^{1}$}

The methods by which samples are taken for analysis of interstitial water and for organic geochemical analysis are described elsewhere in this volume. The coring and sampling techniques, without doubt, have a

\footnotetext{
${ }^{1}$ This section contributed by L. S. Wateman.
}

severe effect on the geochemistry of these materials. The details of this effect remain unknown, but the following factors should be noted.

Drilling fluid (commonly sea water) is pumped from the surface to the bit to lubricate the bit and to carry cuttings around the anulus to the surface. This drilling fluid may significantly change the pore water composition, particularly in more porous sediments and in materials that have been fragmented or mixed by the drilling action.

Removing the materials from in situ pressure and temperature conditions to laboratory conditions will have a profound effect on the solubility of gases dissolved in the interstitial water, and the amount of and ratios between dissolved chemical species in the interstitial water may be altered.

From the moment that a core is extruded onto the deck, interaction of the core with the air takes place-to a limited extent through the plastic liner itself, and to a much greater extent through the cut surface of the split core. This interaction is dominated by, but not limited to, drying by evaporation. Cores with a high salt content may gain water; oxidation of sediments begins at once; etc.

When the cores are cut into sections, the sediments are contaminated at once by airborne bacteria. When incubated at the ambient temperature of the shipboard laboratory, these microorganisms can alter the composition of the interstitial water and gases, and also render analyses of organic geochemistry invalid.

Ideally, samples for geochemical analyses should be obtained and processed immediately upon the arrival of the core barrel on deck. Such speed was not always practical, however, and delays of 8 or more hourswhere cores were left at room temperature-before sampling were common. Some sections from Hole 62.1 were stored at $4^{\circ} \mathrm{C}$ for many days before they were sampled. Comparison of measurements made on the interstitial water squeezed from sediments show that values of Eh and $p \mathrm{H}$ vary widely, depending on the swiftness with which the samples were obtained and analyzed. Samples collected and processed soon after cores were recovered show a much greater internal consistency with respect to $\mathrm{Eh}$ and $\mathrm{pH}$ measurements, and changes appear to be systematic with depth.

The nature and degree of disturbances to the cores have been taken into account by the paleontologists and geologists producing this report. Where the core barrel was invaded extensively by seawater, sections were not processed with respect to weight, natural gamma radiation, gamma ray attenuation or sonic velocity, nor were they opened. Where examination of the split sections showed great disturbance, no samples 
for paleomagnetism or for interstitial water analysis were taken. Wherever possible, the location and type of deformation is shown on the visual core descriptions to assist in evaluating results and in the selection of samples for future work.

Samples for further research should be requested with care after studying the visual core descriptions and the photographs. Because the cores slip inside the liners during transport, one should not specify a sample by distance in centimeters below the top of the section, but rather by showing the location of the sample desired on a copy of the visual core description. It is helpful to submit with the request a brief description of how the sample will be used, so that the curator can use best judgment in taking the sample.

\section{SUMMARY OF CORE PROCESSING}

Cores recovered on Leg 7 were, in general, processed according to procedures outlined in Appendix II, Volume II of the Initial Reports of the Deep Sea Drilling Project (1970). A summary of these procedures is given here, together with such exceptions as are applicable.

The contents of thirty-foot core barrels-commonly in a plastic liner-were received from the drilling crew. Harder materials were cored without a liner to improve recovery, and these exceptions are noted in the text. The materials were cut into 150-centimeter sections and capped for processing. Most unopened 150centimeter sections which appeared to be full and representative were 1) weighed, the tare weight subtracted, and the saturated bulk density calculated; 2) X-rayed; 3) scanned for natural gamma radiation; 4) scanned by a gamma-ray attenuation device (GRAPE), and the saturated bulk density and porosity calculated; and, 5) measured for sonic velocity. A device designed to measure the electrical conductivity of the cores was tested on some unopened cores. Upon the recommendation of the chairman of the JOIDES Advisory Panel on Heat Conductivity, no heat conductivity measurements were made on Leg 7.

Upon conclusion of the above measurements, the sections were split in half longitudinally. In the case of plastic sediments, the plastic liner was cut on opposite sides with a circular saw and the sediments were cut with a wire. In the case of semi-indurated materials, the liner was cut as above, the semi-indurated sediments were cut with a hack-saw blade. In the case of indurated sediments, the sections were split by cutting through both liner and rock with a circular saw. One half of the core was then designated a working half, the other an archive half; and, the two halves were stored in plastic D tubes. The archive half was described, photographed in both black and white and color, and stored at about $4^{\circ} \mathrm{C}$. Penetrometer measurements were made on the working half, and then this half was sampled and stored also.

\section{Penetrometer}

Penetrometer measurements were made to give a relative indication only of the induration of unlithified sediment, and it should not be interpreted to be a measure of sediment strength. The technique used is described in Society of Testing and Materials (1965).

Because core disturbance and dilution tends to reduce the strength of the cored material, the minimum penetration measured per section is likely to be the value most closely related to the characteristics of the sediment in situ. Therefore, the summary tables included with each site show the minimum penetration per section in centimeters.

Previous policy suggested that these penetrometer measurements be made at three specified intervals along the core. During the processing of cores from Site 62 , it became apparent that more meaningful measurements would result from more careful selection of the test sites, and subsequent measurements were made at intervals which appeared to be representative of the core.

\section{Thermal Conductivity}

On the recommendation of Richard von Herzen, Chairman of the JOIDES Advisory Panel on Heat Flow, the thermal conductivity of cores recovered on Leg 7 was not measured, because 1) no in situ heat flow measurements were made on Leg 7 and 2) no member of the Heat Flow Panel needed such measurements for projected research.

\section{LITHOLOGICAL CONVENTIONS}

Classification of the unconsolidated sediment is shown in Table 1. Generally it follows Olausson (1960). However, pelagic clay, brown clay, or pelagic brown clay are used in lieu of red clay where the color or the origin is obvious. Nannofossil is commonly used rather than Olausson's term nannoplankton, especially for the pre-Pleistocene oozes and chalks.

Most of the consolidated rocks recovered on Leg 7 are carbonates and cherts; their classification is discussed below. For volcanic rocks, the terminology is that of Macdonald (Macdonald and Katsura, 1964; and unpublished notes). For fragmental volcanic rocks the terminology is genetic wherever the origin can be determined (pyroclastic, epiclastic, hyaloclastic). Details of texture and composition generally are given in the visual core descriptions, thin-section and smearslide descriptions, and shore-laboratory reports on grain size and X-ray mineralogy. They enable the reader to name the sediment or rock according to the classification he prefers. 
The following descriptive terms are used for the degree of lithification of carbonate rocks. Oozes have little strength and are readily deformed under the finger or the broad blade of a spatula. Chalks are partly indurated oozes; they are friable limestones that are readily deformed under the fingernail or the edge of a spatula blade. Chalks more indurated than that are simply termed limestones. During the coring process, bedding in chalk ooze is commonly folded by remains coherent, whereas chalk fractures. Generally the chalk in cores is badly shattered, and most of the fragments have irregular tabular shapes normal to the core axis, so that they would be described as shale (for example, fissile) if the rock were argillaceous. Fragments of chalk as thick as 2 or 3 centimeters are rare; most chips are but a few millimeters thick. On the other hand, limestone has been recovered in pieces several centimeters thick. Portions of cores with any of these lithologies commonly alternate with portions of mud or slurry of the same color and grain composition as the adjacent ooze, chalk, or limestone, but ground up and mixed with water and injected into the core barrel during some periodic action that affected the bit on bottom, such as the ship's motion or letting out on the drawworks brake. The mud so-formed differs from ooze in being wetter, in showing near-vertical flowfolding and diapir-like structure, and in grading to or containing less-homogenized portions that still contain recognizable pieces of ooze or chalk.

The cherty rocks are subdivided on the basis of their degree of silicification. Porcelanites (porcellanites) are waxy and dull in luster, and commonly show abundant pores under a hand lens. Where cored specimens are allowed to dry out, their surfaces dry to a matte or checked appearance. Thin-section and X-ray analysis show that the silica in porcelanite is opal and cristobalite, and that a large part of the composition is of montmorillonite or other nonsilica minerals. On the other hand, the name chert is restricted for the dense, glassy rocks. Cherts are markedly purer than porcelanites, and their silica is present as chalcedony or microcrystalline quartz. Both porcelanite and chert have conchoidal fracture and both can scratch steel. The more porous and impure porcelanites commonly can be scratched in return by knife-point.

Color symbols are from the Munsell system. Both the soil color charts (Munsell Color Company, 1954) and the rock color charts (Goddard and others, 1948) were used for comparing with the cores. For the reds, yellows and browns, the soil color charts had more color chips and so was used more frequently. However, the terminology in the rock color chart was always used, whether the symbol was obtained by matching to the soil chart or to the rock chart.

Terminology of sedimentary structures is generally that of the Pettijohn and Potter (1964) atlas and glossary. The term turbidite is used in the sense of many sedimentologists, and as used, for example, in the Leg 1 Initial Core Descriptions (Beall and Fischer, 1969). Graded, partly laminated, sandy beds and laminated silt and clay beds, commonly containing grains of various lithologies (such as, foraminifer tests, palagonite grains, large shards, etc.) at the same level, and sharply separated from the underlying sediment, are called turbidites.

Grain-size terminology is that of Wentworth (1922). The standard sand-silt-clay divisions were employed for granulometric analysis (boundaries at 62 and 4 microns). For carbonate-rich deposits a more significant boundary would have been at 20 microns because it separates most microfossils from nannofossils.

Both optical and X-ray diffraction methods were used for mineralogical determinations. Terminology of minerals identified optically is that of Deer, Howie and Zussman (1962). The method of mutual standards and the degree of development of recognition criteria in the programs to interpret the digital X-ray diffraction patterns are discussed by Rex in Appendix III of Volume IV of the Initial Reports (1970).

TABLE 1

\section{Classification of Unconsolidated Pelagic Deposits}

1. $\mathrm{CaCO}_{3}>60 \%$

a. Recognizable calcareous fossil skeletal remains $<30 \%$ : Chalk Ooze

b. Recognizable calcareous fossil skeletal remains $>30 \%$, add name of fossil group of groups: Nannofossil (Nannoplankton) Chalk Ooze; Foraminiferal Chalk Ooze; ForaminiferalNannofossil Chalk Ooze; etc.

2. $\mathrm{CaCO}_{3} 30-60 \%$

a. Recognizable calcareous fossil skeletal remains $<30 \%$ : Marl Ooze

b. Recognizable calcareous fossil skeletal remains $>30 \%$, add their names: Nannofossil Marl Ooze, etc.

\section{3. $\mathrm{CaCO}_{3} 10-30 \%$}

a. The adjective Calcareous is added to the name: Calcareous Diatom Ooze; etc.

4. Siliceous skeletal remains $>30 \%$

a. Named for the recognizable fossil skeletal remains: Radiolarian Ooze; Diatom Ooze; Radiolarian Marl Ooze; etc.

5. Siliceous skeletal remains $10-30 \%$

a. The adjective Siliceous is added to the name: Siliceous Pelagic Clay; etc.

6. $\mathrm{CaCO}_{3}<30 \%$ and siliceous skeletal remains $<$ $30 \%$
a. Brown Pelagic Clay (Red Clay) 
TABLE 1 - Continued

7. Pyroclastic grains (glass shards, etc.) $>10 \%$

a. The adjective Ashy is added to the name: Ashy Chalk Ooze; etc.

8. Consolidated rocks, turbidites, volcanic rocks, etc. are classified separately.

\section{BIOSTRATIGRAPHIC FRAMEWORK ${ }^{1}$}

Because a large number of paleontologists with different views are participating in the work leading to the initial core descriptions, the JOIDES Advisory Panel on Paleontology and Biostratigraphy recommended a scheme of period/system, epoch/series, age/stage classifications for uniform application in this work. It is probable that no worker will be happy with all of the details of this scheme-indeed, there was not unanimity among the members of the panel that formulated it. But it has been necessary to apply such a scheme uniformly in order that the contributions of diverse authors can be integrated into a coherent whole.

${ }^{1}$ Provided by the JOIDES Panel on Paleontology and Biostratigraphy.

TIME-STRATIGRAPHIC FRAMEWORK

\begin{tabular}{|c|c|c|c|c|c|}
\hline & & & & Stage & $\begin{array}{l}\text { Bibliographic reference to the concept of the stratotype being } \\
\text { applied for the purposes of this manual. }\end{array}$ \\
\hline \multirow{4}{*}{ 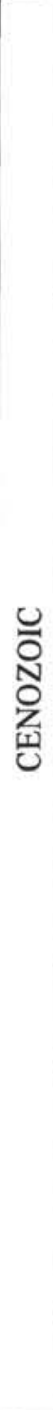 } & 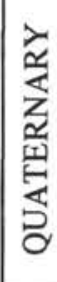 & 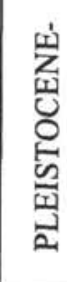 & & Calabrian & $\begin{array}{l}\text { Gignoux, M., 1910. Compt. Rend. Acad. Sci. Paris. 150, } 841 . \\
\text { Gignoux, M., 1913. Ann. Univ. Lyon. } 36 \text {. } \\
\text { Gignoux, M.,1948. Intern. Geol. Congr. 18th (Report published 1950). } \\
\text { Gignoux, M., 1952. Congr. Geol. Intern. Compt. Rend. 19th (Report } \\
\text { published 1954). } \\
\text { Gignoux, M., 1954. Congr. Geol. Intern. Compt. Rend. 19th. p. } 249 . \\
\text { Selli, R., 1962. Quaternaria. 6, 391. }\end{array}$ \\
\hline & \multirow{3}{*}{ 位 } & \multirow[t]{2}{*}{ 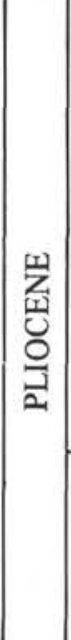 } & 芯 & Piace & $\begin{array}{l}\text { Astian: } \\
\text { de Rouville, P. G., 1853. Description geologique des environs de } \\
\quad \text { Montpellier. Boehm (Montpellier), } 185 . \\
\text { Piacenzian: } \\
\text { Mayer-Eymar, C., 1858. Verhandl. Schweig. Naturforsch. Ges. } 17-19 \\
\quad \text { Aug., 1857. } \\
\text { Pareto, L., 1865. Bull. Soc. Geol. France. (2) 22, } 209 . \\
\text { Gignoux, M., 1915. Bull. Soc. Geol. France. (4) 14, } 338 . \\
\text { Gignoux, M., 1924. Boll. Soc. Geol. Ital. 42, 368. } \\
\text { di Napoli-Alliata, 1954. Congr. Geol. Intern. Compt. Rend. 19th. } \\
\quad \text { p. } 229-234 .\end{array}$ \\
\hline & & & 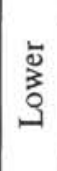 & Zanclian (A)* & $\begin{array}{l}\text { Seguenza, G., 1868. Bull. Soc. Geol. France. (2) 25, } 465 . \\
\text { Baldacci, L., 1886. Mem. Descrit. Carta Geol. Ital. 1, } 1 . \\
\text { Ogniben, L., 1954. Mem. 1st Geol. Mineral. Univ. Padova. } 18 . \\
\text { Wezel, F. C., 1964. Riv. Ital. Pal. Strat. 70, } 307 .\end{array}$ \\
\hline & & 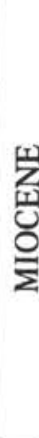 & 总 & Tortonian (B) & $\begin{array}{l}\text { Mayer-Eymar, C., 1867. Catologue systématique et descriptif des } \\
\text { fossiles des terrains tertiariris qui se trouvent au musée fédéral de } \\
\text { Zurich. (Zurich) 2, 13. } \\
\text { Selli, R., 1960. Giorn. Geol. Ann. Museo. Geol. Bologna. (2) 28, 1. } \\
\text { d'Onofrio, S., 1964. Giorn. Geol. Ann. Museo. Geol. Bologna. (2) } \\
\text { 32, 409. } \\
\text { Mayer-Eymar, C., 1858. Verhandl. Schweiz. Naturforsch. Ges. } 17-19 \\
\text { Aug., 1857. } \\
\text { Gino. G. F. et al., 1953. Riv. Ital. Paleont., Mem. 6. 7. } \\
\text { Giannoti, A., 1953. Riv. Ital. Pal. Strat. Mem. VI, 168. } \\
\text { Cita, M. B. et al., 1965. Riv. Ital. Pal. Strat. 71, } 217 .\end{array}$ \\
\hline
\end{tabular}

*Capital letters in parentheses refer to "Notes on Concepts of Stages and Other Boundaries" 


\begin{tabular}{|c|c|c|c|c|c|c|}
\hline & & & 鸪 & Serravallian & $\begin{array}{l}\text { Pareto, M. F., } 1865 \\
\text { Vervloet, C. C., } 1 \\
\text { data on the Tert } \\
\text { 11- } 49 \text {, Schotanus } \\
\text { Cita, M. B. and Pre } \\
\text { fasc. 3, p. } 1-23 \text {. }\end{array}$ & $\begin{array}{l}\text { Bull. Soc. Geol. France, ser. 2, vol. 22, p. } 232 . \\
\text { 66, Stratigraphical and micropaleontological } \\
\text { ary of southern Piedmont (Northern Italy), p. } \\
\text { and Jens, Utrecht. } \\
\text { oli-Silva, I., 1968, Gior, Geol., vol. } 35 \text { (1967), }\end{array}$ \\
\hline & & & & Langh & $\begin{array}{l}\text { Pareto, L., } 1865 . B \\
\text { Cita, M. B. and Silv } \\
\text { hagen, } 1960, R e \\
\text { Cita, M. B. and Elt } \\
\text { 29, 360. }\end{array}$ & $\begin{array}{l}\text { ull. Soc. Geol. France. (2) 22, } 229 . \\
\text { a, I. P., 1960. Intern. Geol. Congr. } 21 \text { st, Copen- } \\
\text { Session, Norden. 22, } 39 . \\
\text { r, G., 1960. Acad. Nazl. dei Lincei. Ser. 8(5), }\end{array}$ \\
\hline & & 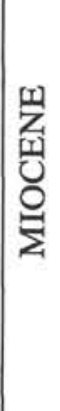 & 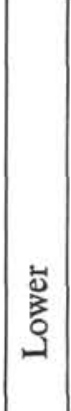 & Burdigalian & 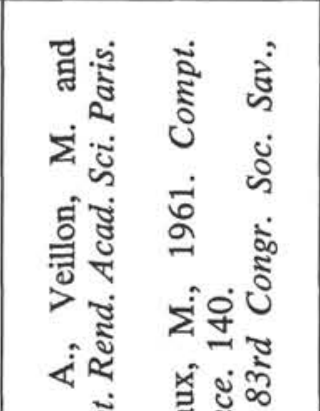 & $\begin{array}{l}\text { Burdigalian: } \\
\text { Depéret, C., 1892. Compt. Rend. Soc. Geol. } \\
\text { France. (11), 145. } \\
\text { Depéret, C., 1893. Bull. Soc. Géol. France. } \\
\text { (3) 21, 263. } \\
\text { Dollfus, 1909. Bull. Serv. Carte Géol. France. } \\
\quad \text { (124) 19, 380. } \\
\text { Drooger, C. et al., 1955. Koninkl. Ned. Akad. } \\
\text { Wetenschap. Verslag Gewone Vergader. } \\
\text { Afdel. Nat. Ser. } 1 \text { (2), 21, } 1 .\end{array}$ \\
\hline $\begin{array}{l}0 \\
0 \\
0 \\
N \\
0 \\
Z \\
\text { Z1 } \\
\text { U }\end{array}$ & 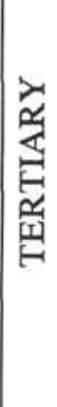 & & & Aquitanian & 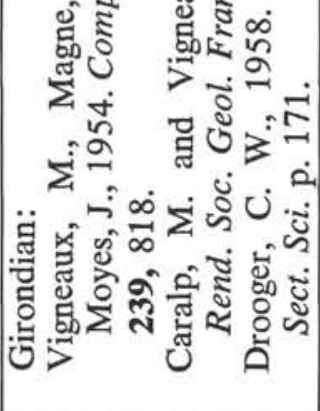 & $\begin{array}{l}\text { Aquitanian: } \\
\text { Mayer-Eymar, C., 1858. Verhandl. Schweiz. } \\
\text { Naturforsch. Ges. 17-19 Aug., 1857, p. } 188 . \\
\text { Tournouer, R., 1862. Bull. Soc. Geol. France. } \\
\text { Ser. 2, 19, 1035. } \\
\text { Drooger, C. W. et al., 1955. Koninkl. Ned. } \\
\quad \text { Akad. Wetenschap. Verslag Gewone Ver- } \\
\text { gader. Afdel. Nat. } \\
\text { Szots, E., 1965. Bull. Soc. Geol. France. (7) } \\
\text { 7, 743. }\end{array}$ \\
\hline & & & & Chattian & $\begin{array}{l}\text { Fuchs, T., 1894. Ja } \\
\text { Gorgës, J., 1952. A } \\
\text { Hinsch, W., 1958. I } \\
\text { Anderson, H. J., } 19 \\
\text { Hubach, H., 1957. }\end{array}$ & $\begin{array}{l}\text { hresber. Ungar. Geol. Anstalt. 10, } 172 . \\
\text { bhandl. Hess. Landesametes Bodenforsch. } \mathbf{4}, 1 . \\
\text { exique Strat. Intern. I } 5 \text { hl. } \\
61 . \text { Meyniana. 10, } 118 . \\
\text { Ber. Naturhist. Ges. Hannover. } \mathbf{1 0 3 .}\end{array}$ \\
\hline & & 至 & & Rupelian & $\begin{array}{l}\text { Dumont, A., } 1849 . \\
\text { Batjes, A., 1958. In }\end{array}$ & $\begin{array}{l}\text { ll. Acad. Roy. Med. Belg. (1) 16, } 370 . \\
\text { Roy. Sci. Nat. Belg. Bull. Mém. } 143 .\end{array}$ \\
\hline & & (3) & & Lattorfian & $\begin{array}{l}\text { Mayer-Eymar, C., } \\
\text { Munier-Chalmas, E. } \\
\text { France. 21, } 478 . \\
\text { von Koenen, A., } 1 \\
1005 . \\
\text { cf. Krutzsch, W. an } \\
\text { Krutzsch, W. and L }\end{array}$ & $\begin{array}{l}\text { 893. Bull. Soc. Geol. France. (3) 21, } 8 . \\
\text { and de Lapparent, A., 1893. Bull. Soc. Geol. } \\
\text { 93-1894. Abhandl. Geol. Spec. Preussen. 10, } \\
\text { Lotsch, D., 1957. Geologie. 6, 476. } \\
\text { otsch, D., 1958. Ber. Deut. Geol. Ges. 3, } 99 .\end{array}$ \\
\hline & & 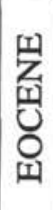 & 总 & Priabon & $\begin{array}{l}\text { Priabonian: } \\
\text { Munier-Chalmas, E } \\
\text { Geol. France. (3 } \\
\text { Roveda, V., 1961. } \\
\text { Fabiani, R., 1915. I }\end{array}$ & $\begin{array}{l}\text { P. and de Lapparent, A., 1893. Bull. Soc. } \\
\text { 21, } 471 . \\
\text { Mem. Ital. Pal. Strat. 67, } 153 . \\
\text { Mem Geol. Mineral Univ. Padova. 3, } 1 .\end{array}$ \\
\hline
\end{tabular}




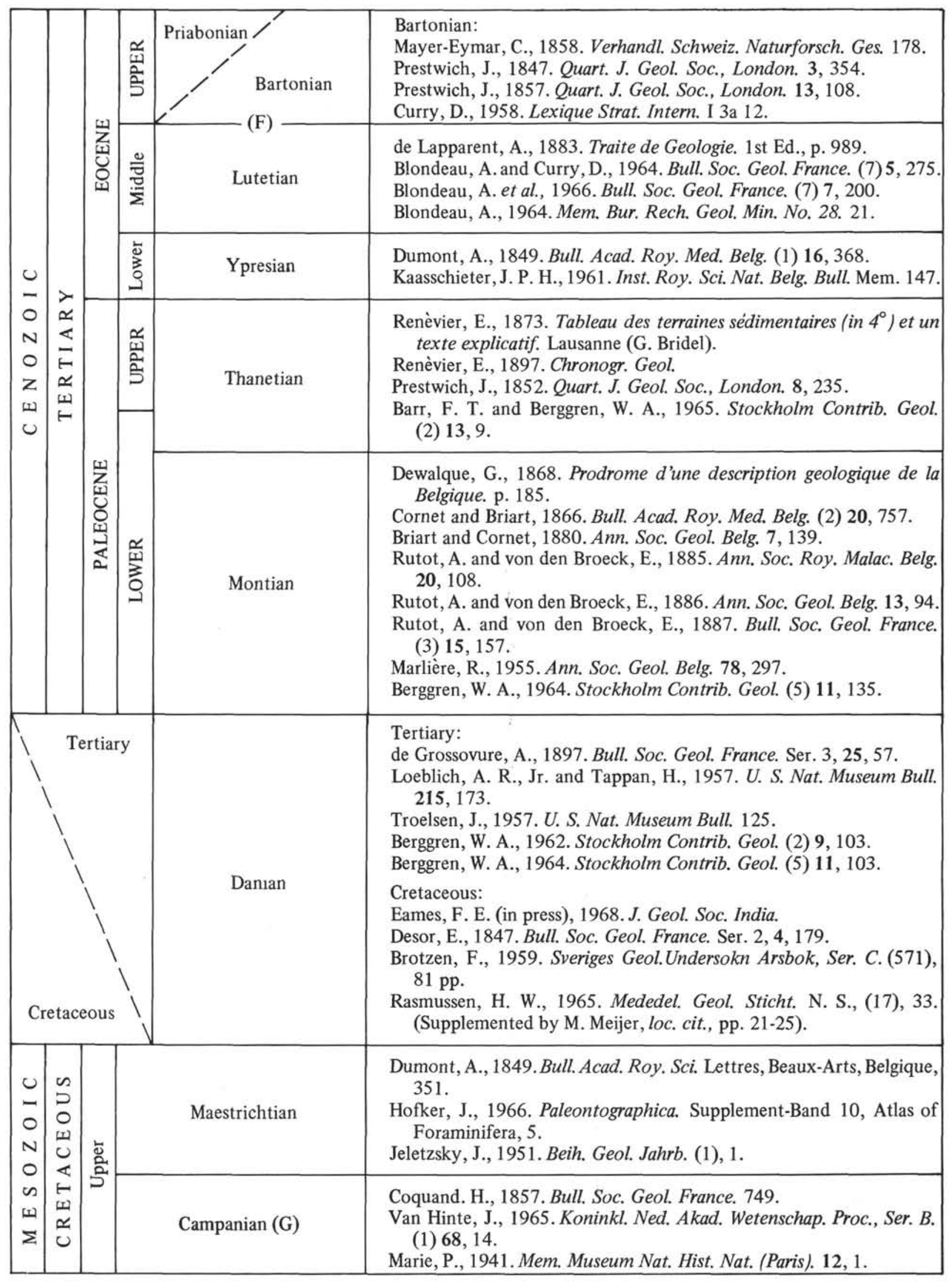




\begin{tabular}{|c|c|c|c|c|}
\hline \multirow{10}{*}{$\begin{array}{c}0 \\
- \\
0 \\
N \\
0 \\
u \\
\Sigma \\
\Sigma\end{array}$} & \multirow{10}{*}{$\begin{array}{l}n \\
0 \\
0 \\
0 \\
01 \\
0 \\
4 \\
0 \\
01 \\
\simeq \\
0\end{array}$} & \multirow{4}{*}{ 舀 } & $\begin{array}{l}\text { Santonian S.S. } \\
(\mathrm{H})\end{array}$ & $\begin{array}{l}\text { Coquand, H., 1857. Bull. Soc. Geol. France, } 749 . \\
\text { Seronie-Vivien, M., 1959. Colloque sur le Crétacé Supérieur Francais } \\
\text { rendus de Congrès des Societes Savantes de Paris et des Depárt- } \\
\text { ments, Comité des Travaux historiques et scientifiques, section des } \\
\text { sciences, sous-section de géologie, tenu a Dijon. Paris (Gauthier- } \\
\text { Villars). 581. }\end{array}$ \\
\hline & & & $\begin{array}{l}\text { Lower } \\
\text { Santonian - } \\
\text { Coniacian (I) }\end{array}$ & $\begin{array}{l}\text { Coquand, H., 1857. Bull. Soc. Geol. France. } 748 . \\
\text { Seronie-Vivien, M., 1959. Colloque sur le Crétacé Supérieur Francais } \\
\text { rendus de Congrès des Societes Savantes de Paris et des Depárt- } \\
\text { ments, Comité des Travaux historiques et scientifiques, section des } \\
\text { sciences sous-section de geologie, tenu a Dijon. Paris (Gauthier- } \\
\text { Villars). p. } 581 \text {. } \\
\text { Schijsfma, E., 1946. Mededel. Geol. Sticht. Ser. C-V (7), 1. }\end{array}$ \\
\hline & & & Turonian & $\begin{array}{l}\text { D'Orbigny, 1842. Les Cephalopodes. (Published by author) } 622 \mathrm{pp} \text {. } \\
\text { D'Orbigny, } 1842 \text {. Les Animaux Mollusques et Raronnes. (Published } \\
\text { by author) } 456 \text { pp. } \\
\text { Lacointre, } 1959 \text {. Colloque sur le Crétacé Supérieur Francais rendus de } \\
\text { Congrès des Societes Savantes de Paris et des Depártments, Comité } \\
\text { des Travaux historiques et scientifiques, section des sciences, sous- } \\
\text { section de géologie, tenu a Dijon. Paris (Gauthier-Villars). } 415 \text {. } \\
\text { Butt, A. A., 1966. Micropaleontology. (2) 12,168. }\end{array}$ \\
\hline & & & Cenomanian & $\begin{array}{l}\text { D’Orbigny, 1842. Les Cephalopodes. (Published by author) } 622 \mathrm{pp.} \\
\text { D'Orbigny, 1842. Les Animaux Mollusques et Raronnes. (Published } \\
\text { by author) } 456 \text { pp. } \\
\text { Marks, P., 1967. Koninkl. Ned. Akad. Wetenschap., Proc., Ser. B } \\
\quad \text { (3), 70,264. }\end{array}$ \\
\hline & & \multirow{6}{*}{ 幽 } & Albian & $\begin{array}{l}\text { Collignon, 1965. Rapport sur L'Etage Albian. In Colloque sur le } \\
\text { Crétacé Inferiéur, Lyon. Mem. Bur. Rech. Geol. Min. (34) (Lyon), } \\
\text { 313. } \\
\text { Casey, 1961. The stratigraphical paleontology of the Lower Creen- } \\
\text { sand. Paleontology. 3, } 487 \text {. }\end{array}$ \\
\hline & & & Aptian & $\begin{array}{l}\text { Fabre-Taxy, S., Moullade, M. and Thomel, G., 1965. A-Les strato- } \\
\text { types de l'Aptien. In Colloque sur le Crétace Inferiéur, Lyon. Mem. } \\
\text { Bur. Rech. Geol. Min. (34), 173. } \\
\text { Casey, R., 1961. The stratigraphical paleontology of the Lower Green- } \\
\text { sand. Paleontology. 3, 487. }\end{array}$ \\
\hline & & & Barremian & $\begin{array}{l}\text { Busnardo, R. 1965. Le stratotype de Barremien. In Colloque sur le } \\
\text { Crétacé Inferiéur, Lyon. Mem. Bur. Rech. Geol. Min. (34) (Lyon), } \\
\text { 101. }\end{array}$ \\
\hline & & & Hauterivian & $\begin{array}{l}\text { Debelmas, J. and Thieuloy, J., 1965. E'tage Hauterivian. In Colloque } \\
\text { sur le Crétacé Inferiéur, Lyon. Mem. Bur. Rech. Geol. Min. (34), } \\
85 .\end{array}$ \\
\hline & & & Valanginian & $\begin{array}{l}\text { Barbier, R. and Thieuloy, J., 1965. E’tage Valanginien. In Colloque } \\
\text { sur le Crétacé Inferiéur, Lyon. Mem. Bur. Rech. Geol. Min. (34), } \\
79 .\end{array}$ \\
\hline & & & Berriasian & $\begin{array}{l}\text { Busnardo, R., Hegaret, G. L. and Magne, J., 1965. Le stratotype du } \\
\text { Berriasien. In Colloque sur le Crétacé Inferiéur, Lyon. Mem. Bur. } \\
\text { Rech. Geol. Min. (34) (Lyon), } 5 \text {. }\end{array}$ \\
\hline
\end{tabular}




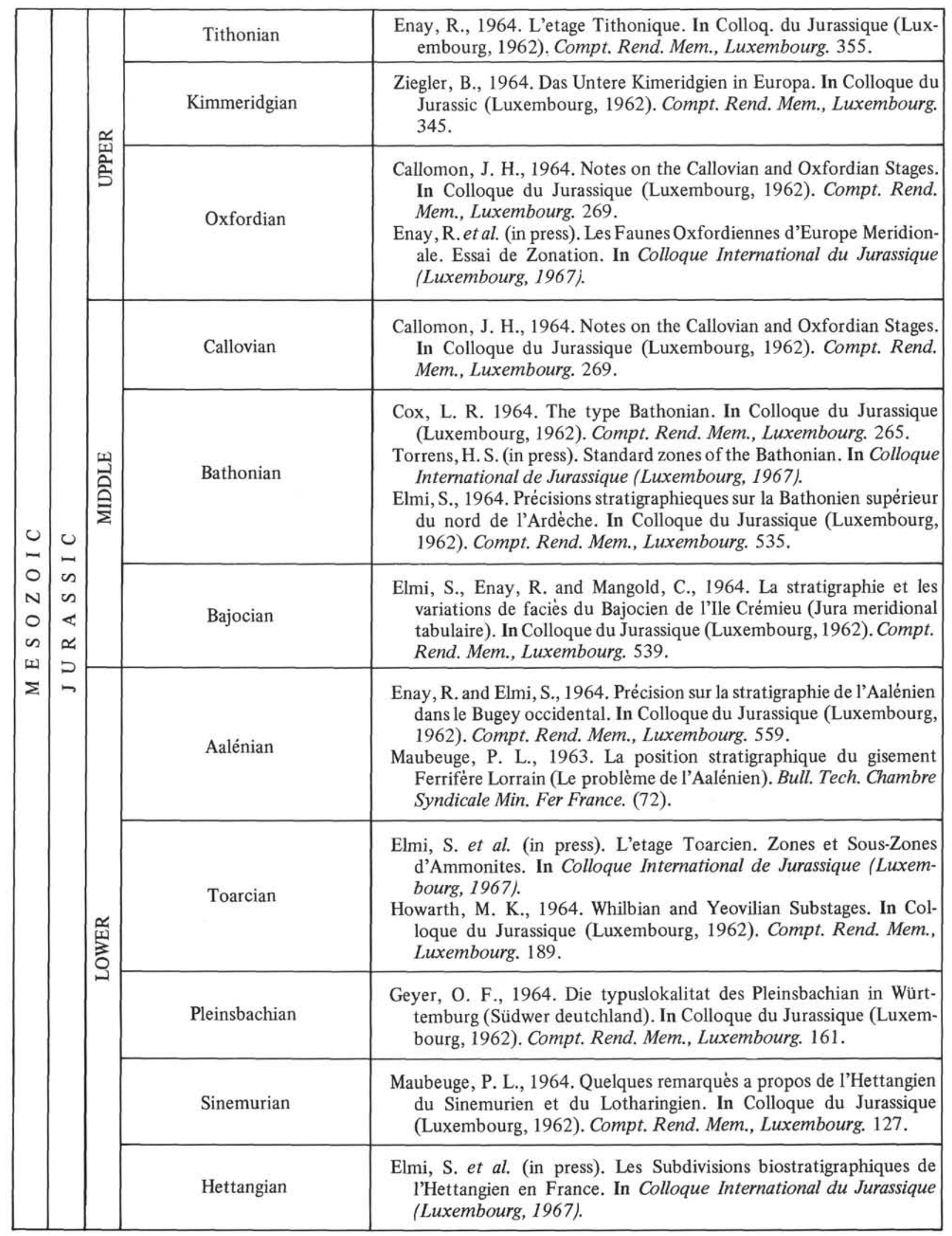




\section{NOTES ON CONCEPTS OF STAGE- AND OTHER BOUNDARIES}

(A) Zanclian is used in preference to Tabianian because the former has been shown to contain a better and more diverse marine fauna which can be used in regional stratigraphic correlation.

(B) Tortonian is placed in the Upper Miocene because:

1) This was its original placement.

2) Although subsequently placed in Middle Miocene, it has now been returned to its original position because the Langhian has been moved up from the top of the Lower Miocene into the Middle Miocene. The type Tortonian is subsequent to beds called "Elveziano" or "Tortonian of Vienna basin", from which many species of Mollusca, especially, have been described as typical of the Middle Miocene. These "Vienna beds" are within the same stratigraphic interval as the beds of the Langhian (=Serravallian of Vervloet, 1966).

(C) The Langhian is restricted, for the purposes of this Manual, to the beds included in the Cessole Formation, and excludes the older horizons included in the Langhian by Cita and Elter.

This essentially follows the usage of Pareto (1865), who directly referred only to the section north of Cessole, which commences with the Cessole Formation. This is in accordance with the results of the work carried out by Drooger and colleagues, who recommended that the first evolutionary appearance of the genus Orbulina occurs from the base of the Middle Miocene, which is a few meters above the base of the exposed Cessole Formation at Cessole.

This is supported by the fact that the base of the French stage Sallomacian (which falls within the Langhian Stage) has always been regarded by the French as the commencement of the Middle Miocene. (The name "Sallomacina" has two years' priority over the term "Vindobonian".) The beds included in the Langhian and Sallomacian Stages are also equivalent to the Badenian Stage of Reiss and Gvirtzman, which covers beds included in the Vindobonian from which virtually all the typical Middle Miocene molluscs were obtained.

(D) The Girondian Stage (Vigneaux et al., 1954) is coextensive with the Aquitanian and Burdigalian, and forms a stratigraphic unit well defined in terms of larger Foraminifera and Mollusca.

(E) Regarding the position of the Oligocene-Miocene boundary, for the purposes of this Manual, the panel has accepted (by majority opinion) the base of the stratotype Aquitanian to represent the base of the Neogene (Oligocene-Miocene boundary), as recommended by the Comité du Néogène Mediterranéen in 1959 (published 1960), 1961 (published 1964), 1964 (published 1966) and 1967 (in press), but not yet formally approved by the IUGS.

There is a radical dichotomy of opinion represented among the panel members, and the two viewpoints are explained below, labelled 1 and 2 .

1. It has been recommended that the base of the stratotype Aquitanian should be taken as the base of the Miocene (and, therefore, the base of the Neogene). The following points apply:

(1) When originally proposed, the Bormidian was regarded as Miocene, and one of the latest publications (Lorenz, 1964), also regarded it as Miocene.

(2) The Bormidian is highly conglomeratic and rests directly upon the Triassic; normally it would not be considered suitable for a stratotype for a standard stage. There has been noindication whether any of the fossils recorded are derived or not (the pebbles of phyllites, schists, etc. obviously are derived). Some fossils were believed later to be Oligocene, but some have been found elsewhere only in beds of Miocene age. To the east of the area the Bormidian is cut out, and the overlying Aquitanian rests directly on nummulitic Oligocene (not present to the west) so that there is an unconformity at the base of the Bormidian-the Triassic underlying it in one area, and nummulitic Oligocene underlying it in another area.

(3) The European stage names on the Tertiary Chart prepared by this panel were all based upon marine megafossil faunas such as Mollusca, Echinoidea, larger Foraminifera, etc. (except for the Paleocene, which originally was based upon plant evidence). The evidence of planktonic foraminifera, however important an asset it may be in the refinement of zonation within and correlation of these stages, did not enter into the primary definitions. It seems quite wrong arbitrarily to select one level of planktonic foraminiferal zonation to define the Miocene-Oligocene boundary; it remains but one part of a much larger field for synthesis. In any case, terms such as "Miocene" and "Oligocene" are timestratigraphic units, and cannot be stratotypified. Consequently, the evidence of megafossils should be considered when 
attempting to find a suitable position for the Miocene-Oligocene boundary.

(4) In the Marnes Blanches de Bernachon, which immediately and conformably underlie the stratotype Aquitanian, there are 7 species of Gastropoda, 9 species of bivalvia, and 20 species and 1 subspecies of Ostracoda, all of which occurred in the overlying Miocene faunas, but have not been found anywhere else in beds regarded as being of Oligocene age. There were a few Ostracoda having known long ranges, but not a single mollusc or ostracod previously known only from the Oligocene or from Oligocene and older beds. This fauna is to be regarded as Neogene and Miocene. In the same beds are found Miogypsina at a more advanced stage of evolution than those of the Eochattian of Bunde. These beds rest unconformably upon nummulitic Middle Oligocene.

(5) In the Nordic Province of Northwestern Europe, the fauna of the Vierländer Stage, although originally regarded as Aquitanian, was later regarded by Kautsky (1925) as being of Burdigalian or even younger age. Consequently, in this Nordic province, there are no basal Miocene megafossil faunas at all available for comparison with the megafossil faunas of the stratotypes of the Chattian, Eochattian and Neochattian. Furthermore, it is evident that the top ends of the ranges of the megafossils in the stratotype Chattian are completely unknown since some of them may well (and probably do) range up into basal Miocene age of much of the Eochattian-Neochattian succession were not realized, such extensions of ranges would never come to light.

(6) With regard to the Eochattian-Neochattian succession it is perhaps significant that: (a) there are several common molluscan species in the Neochattian of which there is no sign in the Eochattian, and (b) there are three levels in the Eochattian at which derived Liassic ammonites occur.

(7) The fauna of the Escornebéou beds as published by Butt (1966) was regarded by him (and Drooger) as late Oligocene ("Chattian"). Not only does this material contain derived material from at least two older levels, and not only do the beds in the area rest unconformably on the Cretaceous, but the faunas include good Globigerinoides which correlate the material with material within the type Aquitanian at the oldest. This material is therefore younger than the Neochattian.

(8) Conclusions: The terms "Miocene" and "Oligocene" are time-stratigraphic units and cannot be stratotypified. Miocene faunas occur beneath the stratotype Aquitanian, and at Escornebéou (where they were called Oligocene). Much of the Eochattian-Neochattian succession can reasonably be regarded as basal Miocene. Useful levels of changes in planktonic foraminiferal faunas are certainly to be used to refine the time-limits within which successions of megafossil faunas occur, but any single one of these alone should not be taken to define a boundary such as "Miocene-Oligocene" without synthesizing the planktonic foraminiferal faunal evidence with that of the megafossils. Any attempt to take the "Miocene-Oligocene" boundary at the incoming of Globigerinoides (i.e., base of stratotype Aquitanian) would result in a large number of molluscan, echinoid, larger foraminiferal, etc. faunas having their ranges extended a very short distance down into the "Oligocene" (sic), at which level there is not only a very noticeable faunal change in many groups of fossils (justifiably taken as the Neogene-Palaeogene boundary) but very often evidence of unconformity in the Alpine-Himalayan region (used in a broad sense). It seems to be highly undesirable to have a major faunal change occurring a short distance below one of relatively minor significance, and to use the latter rather than the former as a "MioceneOligocene" boundary.

2. The stratigraphic extent of the Bormidian can be shown in terms of planktonic foraminiferal zones to include much of the interval ascribed to the Eochattian and Neochattian of Northern Germany. The uppermost part of the Bormidian is approximately at the same level as the middle part of the Neochattian, and both are prior to the Globigerinoides datum which can be recognized at the base of the stratotype Aquitanian. This Globigerinoides datum, as expressed in the stratotype Aquitanian, was recommended in 1959 and reaffirmed in 1963 and 1967 , by the Neogene Commission on Mediterranean Neogene as the horizon to be taken to mark the base of the Miocene. The base of the Bormidian falls within the upper part of the Eochattian succession, while the lower part of Eochattian succession, has been correlated, Hubach 
(1957), and Anderson (1961) with the type Kassel Sands representing the type Chattian. Therefore, there is a prima facie case for regarding the Bormidian as post-Chattian, but pre-Aquitanian. German workers have long regarded the successions seen at Kassel, Doberg and Astrup as being a single major lithological unit, and have considered them as Oligocene. However, where Beyrich (1854 and 1858) did not discuss the present exposure at Astrup, he did discuss the beds at Doberg which include both Eochattian and Neochattian. Therefore, in Beyrich's terminology, the term "Oligocene" should be applied, not only to the Kassel Sands, but also to the succession at Doberg.Miogypsina septentrionalis occurs from near the exposed base of the succession at Doberg (Bed Number 10 of Hubach). This horizon is referable to Zone P.19 of Blow, and also was correlated by Hubach and Anderson to be within the interval of the type Kassel Sands. Furthermore, the latest horizon recognized within the Boom Clay of Belgium (type Rupelian) is also within Zone P. 19. Thus, in agreement with the work of Batjes (1958), there is a reasonable case for considering the Chattian as part equivalent, at least, of the later parts of the Rupelian. The range of Miogypsina ss. must include a part of the Oligocene, and, therefore, cannot be used to decide Neogene or Paleogene affinities.

(F) The Biarritzian Stage has been shown to be partly upper Lutetian and partly lower Auversian. Curry (1967) has suggested that the term "Auversian" covers a recognizable and useful sequence, although it is not quite as extensive stratigraphically as suggested by its usage by some previous French workers. Since the terms Biarritzian and Auversian are provincial in nature they are not used in this manual.

(G) Van Hinte (1965) erected a neostratotype for the Campanian which contains planktonic foraminiferal faunas in the lower part and orbitoids in the higher part. The Campanian planktonic foraminiferal faunas are, from analysis of Van Hinte's figured forms (by Pessagno and Blow), an assemblage which is long-ranging in the broad concept of Campanian, but is not likely to be that which occurs in immediately pre-Maestrichtian horizons. There is no justification for accepting Van Hinte's supposition that $G$. calcarata bearing beds (his Unit $G$ ), immediately overlie the neostratotype $G$ of Van Hinte. In support of this, Blow (unpublished) has observed a single broken specimen of $G$. calcarata presumably from the same Unit G from which Van Hinte recorded his planktonic faunas. In view of the fact that the occurrence of $G$. calcarata is sporadic and the fauna from the neostratotype is very much restricted in diversity and in number of species, it appears that Van Hinte's Unit G is in part, at least, representative of the G. calcarata zone. However, there is an interval between the top of Unit $G$ and the first horizon of occurrence of undoubted orbitoids (e.g. Orbitoides media) which have been accepted by many authors as characteristic of Maestrichtian.

It should be noted that many small "Orbitoides" occur in the interval between the first occurrence of $O$. media and the top of the planktonic foraminiferal fauna of Bed G. These forms (e.g. Schlumbergeria) have been accepted as Campanian forms by many authors; therefore, at least the lower half of Van Hinte's Unit F must be considered as Campanian, whereas the upper half of Unit $\mathrm{F}$ and the younger horizons should be ascribed to Maestrichtian. Because of this, this manual shows $G$. calcarata disappearing just prior to the Campanian-Maestrichtian boundary and $G$. ventricosa disappearing at or very near the Campanian-Maestrichtian boundary.

(H) Santonian s.s. is that part of the Santonian represented by the stratotype.

(I) Beneath the exposed beds of the stratotype Santonian is an interval, part of which is undoubtedly Coniacian as represented in its "stratotype", but between the two there are both beds and faunas which have not been unambiguously differentiated.

(J) The Vraconian of certain Continental authors is here artibrarily included as low Cenomanian.

\section{DATA PRESENTATION}

Every effort has been made to include in this volume as much as possible of the original data collected aboard ship or on shore, in the hope that readers' requests for samples can be guided by as much factual information as we have.

At the same time, the users of this volume may need more generalized graphical summaries of the data. Therefore, in addition to the highly generalized graphic logs in the introductory chapter, for each individual Site Report we present the data graphically at three scales: 1) a site summary $\log , 2$ ) individual core barrel (9 meters) legs, and 3) individual section (150 centimeters) descriptions. 
These graphic logs are arranged hierarchically. The site summary log (in pocket at end of this volume) may be consulted first, and in the body of the test Core 1 is followed by the sections in that core barrel; then Core 2 , etc. It is hoped that this arrangement will allow users of this volume to identify quickly any samples they wish to request.

Each Site Report includes a diagram showing the rate of accumulation of sediments at that site, and the reader should know how the diagrams were constructed. The scale on the left is in millions of years, and is modified from Berggren (1969) by the addition of nannoplankton and radiolarian zones. The correlations among these three different types of zones represents the best estimates of the shipboard paleontologists, at the time the graphs were drawn. The abscissa is simply in meters.

Points are drawn on the graph where the spacing of paleontologically controlled samples permits the placement of a boundary between two zones to within a few meters. Where greater uncertainty exists, the limits of the uncertainty are indicated by a bar or box on the diagram.

The slope of the line through the points is the rate of sediment accumulation, ignoring the effects of postdepositional compaction, and of possible unconformities and diastems. No significance is attached to minor bends in the curve; doubtless, most of these are artifacts produced by our uncertainties in the relations of paleontological zones to the radiometric time scale, and to one another.

\section{REFERENCES}

Anderson, H. J., 1961. Meyniana. 10, 118.

Batjes, D. A. J., 1958. Foraminifera of the Oligocene of Belgium. Inst. Roy. Sci. Nat. Belg. Bull. Mem. 143.

Beall, A. O., Jr. and Fischer, A. G., 1969. Sedimentology. In Ewing, M., et al., 1970. Initial Reports of the Deep Sea Drilling Project, Volume I. Washington (U. S. Government Printing Office), 521.

Berggren, W. A., 1969. Cenozoic chronostratigraphy, planktonic foraminiferal zonation and the radiometric time scale. Nature. 224, 1072.

Beyrich, E., 1854. Über die Stellung der Hessischen Tertiärbildung. Ber. Verhandl. Preussen Akad. Wiss. Ber. 640 .

1858. Über die Abgrenzung der Oligocänen Tertiärzeit. Monatsber, $\mathrm{kgl}$. Preussen Akad. Wiss. Ber. 54 .

Butt, A. A., 1966. Late Oligocene Foraminifera from Escornebéou, S. W. France. Utrecht (Schotanus \& Jens).

Cita, M. B. and Elter, G., 1960. La posizione stratigrafica delle marne a Pteropodi delle Langhe della
Collina di Torino ed il significato cronologico del Langhiano. Accad. Nazl. dei Lincei. Ser. 8 (5), 29, 360.

Curry, D. 1967. Correlations within the Anglo-ParisBelgian Palaeogene Basin. Proc. Geologists' Assoc.

Deer, W. A., Howie, R. A. and Zussman, J., 1962. Rock-Forming Minerals. Volumes 1-5. London (Longmans, Green and Co., Ltd.).

Eames, F. E., (in press), 1968. On Cretaceous-Tertiary boundary. J. Geol. Soc. India.

Gealy, E. L. and Gerard, R. D., 1970. In situ petrophysical measurements in the Caribbean. In Bader, R. D., et al., 1970, Initial Reports of the Deep Sea Drilling Project, Volume IV. Washington (U. S. Government Printing Office), 267.

Goddard, E. N., and others, 1948. Rock color charts. Nat. Res. Council, Washington, D. C. (republished by Geol. Soc. Am.), 8 p.

Hubach, H., 1957. Das Oberoligocän des Doberges bei Bunde in Westf. Ber. Naturhist. Ges. Hannover. 103, 1 .

Kautsky, 1925. Abhandl. Geol. Landesamst. Ber. N. F., 97,1 .

Lorenz, L., 1964. Bull. Soc. Geol. France. Ser. 7, 6, 192.

Macdonald, G. A. and Katsura, T., 1964. Chemical composition of Hawaiian lavas. J. Petrol. 5, 82.

Munsell Color Company, 1954. Munsell Soil Color Charts. Baltimore (Munsell Color Co., Inc.), 23 p.

Olausson, E., 1960. Descriptions of sediment cores from the central and western Pacific with adjacent Indonesian region. Reps. Swed. Deep-sea Exped., 1947-1948. 6, fasc. 5, 161.

Pettijohn, F. J. and Potter, P. E., 1964. Atlas and Glossary of Primary Sedimentary Structures. New York (Springer-Verlag), $305 \mathrm{p}$.

Rasmussen, H. W., 1965. Mededel. Geol. Stricht. N. S. (17), 33

Reiss, Z. and Gvirtzman, G., 1966. Borelis from Israel. Eclog. Geol. Helv. (1), 59, 437.

Skinner, B. J., 1966. Thermal expansion. In Clark, S. P., Jr. (Ed.), Handbook of Physical Constants. Geol. Soc. Am., Mem. 97.

Van Hinte, J. E., 1965. The type Campanian and its planktonic Foraminifera. Koninkl. Ned. Akad. Wetenschap. Proc., Ser. B. (1), 68, 8 .

Vervloet, C. C., 1966. Stratigraphical and Micropaleontological Data on the Tertiary of Southern Piedmont (Northern Italy). University Utrecht. Utrecht (Schotanus \& Jens).

Vigneaux, M., Magne, A., Veillon, M. and Moyes, J., 1954. Compt. Rénd. Acad. Sci. Paris. 239, 818.

Wentworth, C. K., 1922. A scale of grade and class terms of clastic sediments. J. Geol. 30, 377. 